\section{Austria taken to court for inadequate laws on animal welfare}

\section{Brussels}

Austria is to be taken to the European

Court of Justice by the European

Commission over claims that it has

failed to implement adequately

European animal-welfare rules on the

care of stock animals that are being

raised for use in experiments.

The rules form part of directive 86/609/EEC on the "protection of animals used for experimental and other scientific purposes". The commission says that legislation covering the use of animals in experiments in Austria falls well short of the standards required by the directive. The court can order Austria to bring its regulations in line with European Union law, and levy fines of around 100,000 euros (US\$98,000) a day if that ruling is ignored.

The commission says that Vienna has failed to adopt rules in the directive that apply to research centres that breed animals on their own premises, including rules on the general care and accommodation of animals, the role of responsible individuals, and the recording of data on breeding and supplying establishments.

But Andreas Bichl, head of the animal facility at the Research Institute of Molecular Pathology in Vienna, argues that "animals bred as in-house stock are not regulated at present and do not have to be recorded". He argues that such animals are protected under general animal-cruelty laws, but not by specific legislation for experiments.

Austria should have implemented the directive by 1 January 1995, under its terms of accession to the European Union. At the time, the commission concluded that Austria had not complied, and launched an infringement procedure. Austria amended its law, but the commission has now concluded that the reforms were not comprehensive enough.

"If veterinary inspectors want to inspect our facilities, they have to adhere to the laboratory-animals law, which covers only 20 per cent of animals in house," says Bichl. "Mice have a high rate of reproduction and [under the directive] we would have to record every litter; it would be a lot of administrative work."

The commission has also threatened Belgium with court action for allegedly giving "insufficient recognition of data" from experiments in other member states, to avoid unnecessary duplication of animal experiments. Keith Nuthall

\title{
International science council names first female president
}

\section{Irvine, California}

Marine ecologist Jane Lubchenco of Oregon State University will be the next president of the International Council for Science (ICSU), becoming the first woman to head the Paris-based organization.

Lubchenco will take on the duties of president-elect of the organization - formerly known as the International Council of Scientific Unions - in March 2001 under plans agreed last September at the ICSU general assembly in Cairo. She will begin her threeyear term as president in 2002 at the next general assembly, scheduled for Rio de Janeiro.

"I am thrilled," says Lubchenco, whose election was announced last week at a meeting of the US National Science Board, on which she also serves. "I consider it a high honour and daunting responsibility. I view science as a key element in enabling a prosperous, secure and healthy future for all of us."

Lubchenco is the Valley professor of marine biology at Oregon State University, where she studies rocky-shore ecology, and will be the first US president of ICSU since 1976. ICSU's board had actively been seeking a US scientist for the nomination this time. "She is the kind of person science needs in a leadership role," says John Boright, executive director for international affairs at the US National Academy of Sciences.

Lubchenco, a former president of the American Association for the Advancement of Science, is experienced in international science diplomacy, and attended last week's meeting of the World Economic Forum in

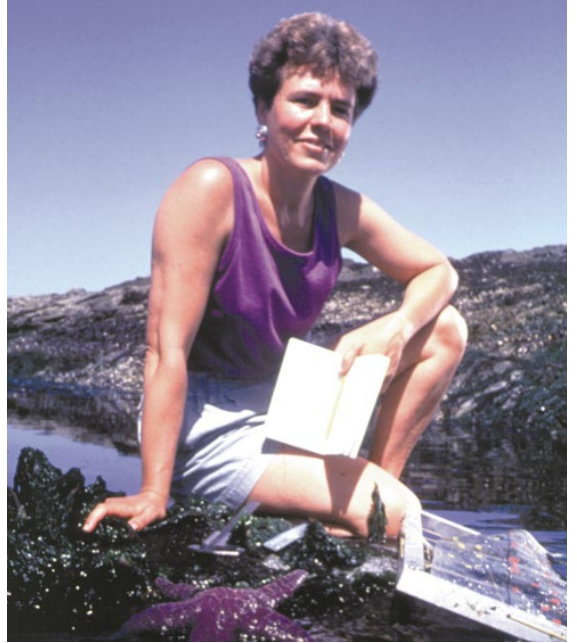

Lubchenco: expected to keep environmental issues high on the political agenda.

Davos, Switzerland. She hopes to use her ecological background to keep issues such as climate change high on the international political agenda.

ICSU recently named a new executive director, Larry Kohler, an American who has lived in Europe for many years, and who took up his new post on 1 January. ICSU's secretary general is Harold Mooney, a biologist at Stanford University.

There has been unease in some quarters about the ascendance of Americans in key posts in ICSU. But US officials argue that this could result in greater US support for international scientific efforts.

Rex Dalton

\section{Biotech companies attack NIH rules}

\section{Washington}

Guidelines on research tools issued recently by the US National Institutes of Health (NIH) came under fire last week from representatives of several small biotechnology companies at a symposium on intellectual property organized by the National Academy of Sciences.

The guidelines advise researchers in general who use NIH money to generate tools such as reagents and new transgenic technologies - against demanding 'reachthrough' rights that claim future intellectual property on products generated from a tool's use (see Nature 403, 10;2000).

But Robert Blackburn, vice-president and chief patent council of Chiron, a private biotech company based in Emeryville, California, said that biotech companies need both reach-through rights and licensing arrangements - without compensation for their intellectual property, they would have a difficult time surviving.

Intellectual property gives biotech companies "the right to be in the market", says Evelyn McConathy, a patent lawyer with the Philadelphia firm Dilworth Paxson LLP, adding that the market, not government policy, should drive licensing deals.

But she admits that a "large outcry" followed DuPont's initial demands that researchers accept reach-through terms if they use Cre-lox, which allows genes to be removed from specific cells and tissues. The outcry forced the company to allow nonprofit researchers freely to use the technology, which was developed using NIH funding (see Nature 394, 819; 1998). 